\title{
KAJIAN TOKSISITAS EKSTRAK DAUN MINT (Mentha arvensis L.) TERHADAP MORTALITAS ULAT KROP KUBIS (Crocidolomia pavonana F.)
}

\author{
Teresia Clara Ekaristi¹, Nur Yasin'1, Agus Muhammad Hariri ${ }^{1}$ \& Subeki ${ }^{2}$ \\ ${ }^{1}$ Jurusan Agroteknologi, ${ }^{2}$ Jurusan Teknologi Hasil Pertanian, Fakultas Pertanian Universitas Lampung \\ Jl. Prof. Soemantri Brodjonegoro, No. 1, Bandar Lampung 35145
}

\begin{abstract}
ABSTRAK
Ulat krop kubis dapat merusak tanaman dengan cara memakan bagian titik tumbuh kubis. Untuk mengendalikannya dapat digunakan insektisida botani. Salah satu diantaranyaadalah dengan mengkaji ekstrak daun mint (Mentha arvensis L.). Penelitian ini bertujuan untuk mengetahui pengaruh ekstrak daun mint terhadap Crocidolomia pavonana $\mathrm{F}$. Penelitian ini dilaksanakan di Laboratorium Komponen Bioaktif Jurusan Teknologi Hasil Pertanian dan Laboratorium Bioteknologi Pertanian, Fakultas Pertanian Universitas Lampung pada bulan Januari sampai Oktober 2012. Penelitian dilakukan melalui 3 tahap uji hayati. Uji hayati pertama dilakukan untuk mengetahui aktivitas insektisida antara fraksi lapisan air $\left(\mathrm{H}_{2} \mathrm{O}\right)$ dan etil asetat (Et $\mathrm{OAc}$ ) tehadap mortalitas C. pavonana F. Fraksi yang aktif adalah fraksi lapisan air. Fraksi ini diuapkan dan dielusi menjadi 6 fraksi yaitu $100 \%$ $\mathrm{H}_{2} \mathrm{O}, 20 \% \mathrm{MeOH} / \mathrm{H}_{2} \mathrm{O}, 40 \% \mathrm{MeOH} / \mathrm{H}_{2} \mathrm{O}, 60 \% \mathrm{MeOH} / \mathrm{H}_{2} \mathrm{O}, 80 \% \mathrm{MeOH} / \mathrm{H}_{2} \mathrm{O}$, dan $100 \% \mathrm{MeOH}$ untuk uji hayati kedua. Fraksi $100 \% \mathrm{H}_{2} \mathrm{O}$ menunjukkan aktivitas insektisida lebih tinggi dibandingkan dengan fraksi lainnya. Fraksi $100 \% \mathrm{H}_{2} \mathrm{O}$ dievaporasi hingga diperoleh residu dan dibuat konsentrasi 10.000, 5.000, 2.500, 1.250, 625, dan 312,5 ppm, untuk uji hayati ketiga. Dari uji ini diketahui bahwa aplikasi ekstrak daun mint pada konsentrasi $10.000 \mathrm{ppm}$ mulai 48 jsa dapat menyebabkan mortalitas ulat $C$. pavonana F. lebih tinggi dibandingkan dengan konsentrasi 5.000, 2.500, 1.250, 625, dan 312,5 ppm.
\end{abstract}

Kata kunci : Crocidolomia pavonana, ekstrak daun mint, insektisida botani, Mentha arvensis, Ulat krop kubis.

\section{PENDAHULUAN}

Tanaman sayuran merupakan salah satu tanaman penting dalam bidang pertanian di Indonesia. Sayuran merupakan salah satu bagian penting dalam menu makanan masyarakat Indonesia.Sayuran banyak mengandung berbagai vitamin seperti vitamin $\mathrm{A}, \mathrm{B}, \mathrm{C}$, $\mathrm{D}, \mathrm{E}, \mathrm{K}$ serta serat makanan yang sangat diperlukan oleh tubuh manusia. Komposisi gizi pada sayuran antara lain protein $1,7 \%$, lemak $0,2 \%$, karbohidrat $0,1 \%$, dan abu 0,16\% (Sastrahidayat dan Soemarno, 1991 dalam Supriyati, 2001).

Salah satu tanaman sayuran yang banyak dibudidayakan di Indonesia adalah kubis (Brassicaoleracea L.). Kubis merupakan tanaman semusim yang bersifat perdu dan banyak dibudidayakan di daerah dataran tinggi (Dinas Pertanian Provinsi Lampung, 2010).

Dalam upaya meningkatkan produksi kubis terdapat beberapa faktor yang menjadi penghambat. Salah satu diantaranya adalah serangan hama ulat krop kubis (Crocidolomia pavonana F.). Serangan hama ulat ini dapat menyebabkan penurunan produksi kubis. Ulat krop kubis secara langsung dapat merusak tanaman kubis dengan cara memakan daun yang masih muda. Ulat krop kubis juga dapat memakan daun yang agak tua dan kemudian menuju ke bagian titik tumbuh sehingga bagian titik tumbuh habis. Dengan demikian, pembentukan krop kubis akan terhambat (Sunarjono, 2003).

Untuk mencegah serangan hama ulat krop kubis, sebagian besar petani menggunakan insektisida sintetik. Penggunaan insektisidasintetiksecara terus menerus dapat mengakibatkan resistensi serangga dan meninggalkan residu pada produk hasil pertanian. Hal ini sangat berbahaya bagi kesehatan manusia yang mengkonsumsi sayuran dan menimbulkan pencemaran lingkungan. Oleh karena itu,perlu dicari alternatifpengendalian hama dengan cara yang lebih aman, efektif dan tidak meninggalkan residu (Sarjan, 2008).Salah satu alternatif adalah dengan menggunakan insektisida botani yang dibuat dari ekstrak daun mint (Mentha arvensis L.).

Berbagai penelitian sebelumnya menunjukkan bahwa daun mint dapat digunakan sebagai insektisida alami untuk mengendalikan hama Plutella xylostella, Spodoptera litura, dan $C$. pavonana F. (Kardinan, 2004). Oleh karena itu, dalam penelitian ini dilakukan proses ekstraksi dan fraksinasi daun mint untuk memperoleh fraksi aktif yang dapat mematikan ulat krop kubis (C. pavonana $\mathrm{F}$.).

\section{BAHAN DAN METODE}

Penelitian ini dilaksanakan di Laboratorium Komponen Bioaktif Jurusan Teknologi Hasil Pertanian 
untuk ekstraksi dan fraksinasi daun mint. Selanjutnya ekstrak diaplikasikan pada Crocidolomia pavonana $\mathrm{F}$. Penelitian dilakukan pada bulan Januari sampai Oktober 2012.

Langkah-langkah dalam pelaksanaan penelitian ini dimulai dengan penyediaan serangga uji. Penyediaan serangga uji dimulai dengan melakukan pencarian ulat C. pavonana $\mathrm{F}$. dilapangan yaitu pada bunga tanaman sawi. Pada pencarian didapatkan koloni berbagai fase ulat $C$. pavonana $\mathrm{F}$. yang kemudian larva-larva tersebut dilakukan pemeliharan pada berbagai tempat pemeliharaan yang di dalamnya telah diberi tanaman brokoli. Larva instar 1 dan 2 diletakkan pada stoples plastik dengan tutup kain kasa yang telah diberi pakan daun brokoli sebanyak 4 lembar. Sedangkan, untuk larva instar 3 hingga instar 5 diletakkan pada stoples berbeda yang dialasi dengan kertas putih dan diberi pakan daun brokoli. Setiap hari daun diganti dan stoples dibersihkan. Setelah ulat berubah menjadi pupa, pupa diletakkan pada tanah dalam kurungan plastik yang berisi tanaman brokoli, digantungkan kapas yang mengandung madu $50 \%$. Untuk memelihara imago hingga bertelur, telur - telur ngengat $C$. pavonana $\mathrm{F}$. dipindahkan kembali pada stoples yang ditutup kain kasa, yang berisi daun brokoli untuk pakan larva. Larva instar yang digunakan sebagai serangga uji yaitu larva instar 2 yang berumur 3-5 hari.

Langkah selanjutnya adalah ekstraksi dan fraksinasi. Daun mint sebanyak $1 \mathrm{~kg}$ dijemur dengan panas matahari selama 3 hari kemudian diblender dengan blender kering. Sebanyak 300 gr daun mint kering yang telah dihaluskan direndam dalam 51 larutan etanol 96\% selama 14 hari. Setiap hari selama 10 menit dilakukan pengadukan. Filtrat disaring dengan kain saring kemudian diuapkan dengan rotary evaporator menjadi $500 \mathrm{ml}$. Filtrat pekat tersebut kemudian diekstraksi dengan EtOAc (etil asetat) hingga diperoleh (1) fraksi lapisan air dan (2) fraksi lapisan Et OAc. Kedua fraksi tersebut selanjutnya dilakukan pengujian aktivitas insektisida terhadap ulat krop kubis (C. pavonana $\mathrm{F}$.) pada konsentrasi 10.000 ppm, sebagai uji hayati pertama. Dari dua fraksi tersebut didapatkan fraksi lapisan air yang telah terbukti mempunyai aktivitas insektisida terhadap C. pavonana F. Selanjutnya fraksi lapisan air ini diuapkan hingga kering dan dimasukkan ke dalam kolom khromatografi dan dielusi dengan $100 \% \mathrm{H}_{2} \mathrm{O}(500$ $\mathrm{ml}), 20 \% \mathrm{MeOH} / \mathrm{H}_{2} \mathrm{O}(500 \mathrm{ml}), 40 \% \mathrm{MeOH} / \mathrm{H}_{2} \mathrm{O}(500$ $\mathrm{ml}), 60 \% \mathrm{MeOH} / \mathrm{H}_{2} \mathrm{O}(500 \mathrm{ml}), 80 \% \mathrm{MeOH} / \mathrm{H}_{2} \mathrm{O}(500$ $\mathrm{ml})$, dan $100 \% \mathrm{MeOH}(500 \mathrm{ml})$ secara berurutan. Keenam fraksi tersebut selanjutnya dilakukan pengujian aktivitas insektisidaterhadap ulat krop kubis sebagai uji hayati kedua. Dari keenam fraksi tersebut didapatkan fraksi100\% $\mathrm{H}_{2} \mathrm{O}$ yang terbukti mempunyai aktivitas insektisidaterhadap $C$. pavonana $\mathrm{F}$. selanjutnyafraksi $100 \% \mathrm{H}_{2} \mathrm{O}$ diuapkan hingga keringdengan rotary evaporatordan dielusi dengan air pada konsentrasi $10.000,5.000,2.500,1.250,625$, dan 312,5 ppm, sebagai bahan uji hayati ketiga.

Langkah ketiga adalah pengenceran ekstrak fraksi air. Hasil ekstraksi pada berbagai ekstrak fraksi lapisan air diambil sebanyak $5 \mathrm{~g}$ kemudian ditambahkan air sebanyak $500 \mathrm{ml}$ kemudian distirer (diaduk) untuk menghomogenkan. Fraksi air ini merupakan konsentrasi $10.000 \mathrm{ppm}$, kemudian dari ekstrak ini dibuat konsentrasi 5.000 ppm, 2.500 ppm, 1.250 ppm, 625 ppm dan 312,5 ppm. Pengenceran ekstrak fraksi air konsentrasi 5.000 ppm diperoleh dari $250 \mathrm{ml}$ ekstrak fraksi air $10.000 \mathrm{ppm}$ yang ditambah $250 \mathrm{ml}$ air dan distirer. Konsentrasi 1.250 ppm diperoleh dari $250 \mathrm{ml}$ ekstrak fraksi air konsentrasi $2.500 \mathrm{ppm}$ yang ditambah $250 \mathrm{ml}$ air dan distirer. Konsentrasi 312,5 ppm diperoleh dari $250 \mathrm{~mL}$ ekstrak fraksi air konsentrasi $625 \mathrm{ppm}$ yang ditambah $250 \mathrm{ml}$ air dan distirer.

Langkah keempat adalah uji hayati. Dari hasil ekstraksi pertama diperoleh lapisan air $\left(\mathrm{H}_{2} \mathrm{O}\right)$ dan lapisan etil asetat (Et OAc). Selanjutnya lapisan-lapisan tersebut dilakukan uji hayati pertama terhadap serangga uji $C$. pavonana F.Fraksi lapisan $\mathrm{H}_{2} \mathrm{O}$ terbukti mempunyai aktivitas insektisida terhadap $C$. pavonana F. Pada uji hayati kedua, fraksi lapisan air dari uji hayati pertama diuapkan hingga kering dan dimasukkan ke dalam kolom khromatografi dan dielusi dengan $100 \% \mathrm{H}_{2} \mathrm{O}(500 \mathrm{ml}), 20 \% \mathrm{MeOH} / \mathrm{H}_{2} \mathrm{O}(500 \mathrm{ml}), 40 \%$ $\mathrm{MeOH} / \mathrm{H}_{2} \mathrm{O}(500 \mathrm{ml}), 60 \% \mathrm{MeOH} / \mathrm{H}_{2} \mathrm{O}(500 \mathrm{ml}), 80 \%$ $\mathrm{MeOH} / \mathrm{H}_{2} \mathrm{O}(500 \mathrm{ml})$, dan $100 \% \mathrm{MeOH}(500 \mathrm{ml})$ secara berurutan. Enam macam fraksi ini digunakan untuk uji hayati kedua terhadap C. pavonana F. Dari uji hayati kedua diperoleh fraksi $100 \% \mathrm{H}_{2} \mathrm{O}$ yang aktif.

Pada uji hayati ketiga, fraksi $100 \% \mathrm{H}_{2} \mathrm{O}$ dari uji hayati kedua diuapkan dan diencerkansehingga diperoleh konsentrasi 0 ppm, 312,5 ppm, 625 ppm, 1.250 ppm, 2.500 ppm, 5.000 ppm dan 10.000 ppm untuk uji hayati ketiga. Setiap satuan percobaan ekstrak daun mint (baik uji hayati pertama, kedua maupun uji hayati ketiga) terdiri atas stoples dengan tutup kain kasa yang berisi 20 ekor larva instar 2 dan diberi pakan daun brokoli sebanyak 4 lembar yang telah dicelupkan dalam fraksi daun mint yang aktif sesuai dengan tingkat konsentrasi perlakuan dengan 3 ulangan. Sedangkan untuk perlakuan kontrol digunakan 20 ekor larva uji dan diberi pakan daun brokoli sebanyak 4 lembar daun brokoli tanpa residu ekstrak daun mint yang dimasukkan ke dalam stoples dan ditutup kain kasa.

Pada pengamatan dan analisis data, pengamatan dilakukan untuk mengetahui serangga yang mati pada 
24 jam setelah aplikasi. Persentase mortalitas ulat krop kubis yang dapat dihitung dengan rumus sebagai berikut:

$$
\% \text { Mortalitas }=\frac{A}{B} \times 100 \%
$$

Keterangan :

$\mathrm{A}=$ Jumlah serangga yang mati

$\mathrm{B}=$ Jumlah serangga uji

Menurut Hasibuan (2003) sebelum melakukan perhitungan faktor kematian (faktor kematian pada kontrol yang disebabkan oleh faktor lain) harus terlebih dahulu dikoreksi dengan rumus Abbot (1925), dengan rumus sebagai berikut :

$$
\% \text { Kematian Terkoreksi }=\frac{A-B}{100-B} \times 100 \%
$$

Keterangan :

$\mathrm{A}=$ Persentase serangga uji yang mati pada perlakuan $\mathrm{B}=$ Persentase serangga uji yang mati pada kontrol

\section{HASIL DAN PEMBAHASAN}

Mortalitas Crocidolomia pavonana F. pada uji hayati pertama. Hasil penelitian pada uji hayati pertama menunjukkan bahwa fraksi lapisan air pada konsentrasi 10.000 ppm pada 24 jam setelah aplikasi (jsa) lebih aktif dibandingkan fraksi lapisan EtOAc dalam mematikan hama $C$. pavonana F. Fraksi lapisan air menyebabkan mortalitas sebesar 56,93\% dan fraksi lapisan EtOAc sebesar 34,21\% (Tabel 1).

Penelitian ini menunjukkan bahwa fraksi lapisan air $\left(\mathrm{H}_{2} \mathrm{O}\right)$ menyebabkan mortalitas $C$. pavonana $\mathrm{F}$. Menurut Sastrohamidjojo (2004) daun mint mengandung senyawa polar seperti menthol dan menthone. Harwood et al. (1990) dalam Hayes et al. (2007) menyatakan bahwa menthol dan menthone berpengaruh buruk

Tabel 1. Persentase mortalitas terkoreksi $C$. pavonana F. pada fraksi lapisan $\mathrm{H}_{2} \mathrm{O}$ dan Et OAc pada 24 jsa pada konsentrasi 10.000 ppm.

\begin{tabular}{lc}
\hline \multicolumn{1}{c}{ Fraksi } & Mortalitas (\%) \\
\hline Kontrol & $00,00 \mathrm{c}$ \\
Lapisan air $\left(\mathrm{H}_{2} \mathrm{O}\right)$ & $56,93 \mathrm{a}$ \\
Lapisan etil asetat (EtOAc) & $34,21 \mathrm{~b}$ \\
\hline
\end{tabular}

$\mathrm{BNT}=0,94$

Keterangan: Angka yang diikuti huruf sama pada kolom yang sama menunjukkan tidak berbeda nyata menurut uji BNT pada $\alpha_{0,05}$. terhadap ulat Peridoroma saucia Hubner, menurunkan berat tubuh, menghambat nafsu makan, dan mengakibatkan abnormalitas proses ganti kulit larva. Dengan demikian diduga bahwa fraksi lapisan air $\left(\mathrm{H}_{2} \mathrm{O}\right)$ dari ekstrak daun mint juga mengandung senyawa menthol dan menthone yang dapat menyebabkan mortalitas $C$. pavonana $\mathrm{F}$.

Sastrohamidjojo (2004), menyatakan bahwa senyawa tersebut dapat menghambat proses sintesis protein di dalam tubuh serangga. Fraksi lapisan EtOAc termasuk pelarut yang mengandung berbagai senyawa semi polar hingga non polar. Sehingga senyawa tersebut kemungkinan sulit menempel pada daun pakan yang digunakan untuk pengujian.

Mortalitas Crocidolomia pavonana F. pada uji hayati kedua. Hasil penelitian pada uji hayati pertama menunjukkan bahwa fraksi lapisan air lebih aktif dibandingkan fraksi lapisan Et OAc. Oleh karena itu fraksi air digunakan untuk uji hayati lanjutan pada uji hayati kedua. Fraksi lapisan air dimasukkan ke dalam kolom khromatografi dan dielusi dengan $100 \% \mathrm{H}_{2} \mathrm{O}(500$ $\mathrm{ml}), 20 \% \mathrm{MeOH} / \mathrm{H}_{2} \mathrm{O}(500 \mathrm{ml}), 40 \% \mathrm{MeOH} / \mathrm{H}_{2} \mathrm{O}(500$ $\mathrm{ml}), 60 \% \mathrm{MeOH} / \mathrm{H}_{2} \mathrm{O}(500 \mathrm{ml}), 80 \% \mathrm{MeOH} / \mathrm{H}_{2} \mathrm{O}(500$ $\mathrm{ml})$, dan $100 \% \mathrm{MeOH}(500 \mathrm{ml})$ secara berurutan.

Enam macam fraksi ini setelah diujikan terhadap C. pavonana $\mathrm{F}$. menunjukkan bahwa pada 24 jsa, fraksi $100 \% \mathrm{H}_{2} \mathrm{O}$ meyebabkan mortalitas $C$. pavonana $\mathrm{F}$. yang tidak berbeda nyata dengan fraksi $20 \% \mathrm{MeOH} /$ $\mathrm{H}_{2} \mathrm{O}$, akan tetapi berbeda nyata dengan fraksi $40 \%$ $\mathrm{MeOH} / \mathrm{H}_{2} \mathrm{O}, 60 \% \mathrm{MeOH} / \mathrm{H}_{2} \mathrm{O}, 80 \% \mathrm{MeOH} / \mathrm{H}_{2} \mathrm{O}$, dan fraksi $100 \% \mathrm{MeOH}$. Pada 48 jsa, fraksi $100 \% \mathrm{H}_{2} \mathrm{O}$ mengakibatkan mortalitas $C$. pavonana $\mathrm{F}$. sebesar $54,09 \%$, akan tetapi berbeda nyata dengan fraksi $20 \%$ $\mathrm{MeOH} / \mathrm{H}_{2} \mathrm{O}, 40 \% \mathrm{MeOH} / \mathrm{H}_{2} \mathrm{O}, 60 \% \mathrm{MeOH} / \mathrm{H}_{2} \mathrm{O}$, $80 \% \mathrm{MeOH} / \mathrm{H}_{2} \mathrm{O}$ dan fraksi $100 \% \mathrm{MeOH}$. Pada 72 jsa, fraksi $100 \% \mathrm{H}_{2} \mathrm{O}$ dapat menyebabkan mortalitas hama $C$. pavonana $\mathrm{F}$. lebih tinggi sebesar $60,32 \%$, akan tetapi berbeda nyata dengan fraksi $20 \% \mathrm{MeOH} / \mathrm{H}_{2} \mathrm{O}$, $40 \% \mathrm{MeOH} / \mathrm{H}_{2} \mathrm{O}, 60 \% \mathrm{MeOH} / \mathrm{H}_{2} \mathrm{O}, 80 \% \mathrm{MeOH} / \mathrm{H}_{2} \mathrm{O}$, dan fraksi $100 \% \mathrm{MeOH}$ (Tabel 2).

Aplikasi fraksi daun mint kemungkinan memberikan nilai mortalitas yang meningkat seiring dengan interval waktu pengamatan. Fraksi $100 \% \mathrm{H}_{2} \mathrm{O}$ mengandung senyawa polar yang dapat menyebabkan mortalitas C. pavonana F. Fraksi $100 \% \mathrm{H}_{2} \mathrm{O}$ kemungkinan mengandung senyawa menthol dan menthone yang lebih banyak dibandingkan dengan fraksi yang mengandung senyawa campuran air dan metanol. Oleh karena itu bahan aktif yang terdapat dalam fraksi $100 \% \mathrm{H}_{2} \mathrm{O}$ dapat menyebabkan mortalitas $C$. pavonana $\mathrm{F}$. yang lebih tinggi bila dibandingkan dengan fraksi campuran air dan metanol sehingga serangga mati. 
Mortalitas Crocidolomia pavonana F. pada uji hayati ketiga. Hasil penelitian pada uji hayati kedua menunjukkan bahwa fraksi $100 \% \mathrm{H}_{2} \mathrm{O}$ lebih aktif dari pada fraksi $20 \% \mathrm{MeOH} / \mathrm{H}_{2} \mathrm{O}, 40 \% \mathrm{MeOH} / \mathrm{H}_{2} \mathrm{O}, 60 \%$ $\mathrm{MeOH} / \mathrm{H}_{2} \mathrm{O}, 80 \% \mathrm{MeOH} / \mathrm{H}_{2} \mathrm{O}$, dan $100 \% \mathrm{MeOH}$. Oleh karena itu fraksi $100 \% \mathrm{H}_{2} \mathrm{O}$ digunakan untuk uji hayati ketiga. Fraksi $100 \% \mathrm{H}_{2} \mathrm{O}$ ini digunakan untuk pengujian terhadap $C$. pavonana $\mathrm{F}$. pada konsentrasi $10.000 \mathrm{ppm}, 5.000 \mathrm{ppm}, 2.500 \mathrm{ppm}, 1.250 \mathrm{ppm}, 625 \mathrm{ppm}$, dan $312,5 \mathrm{ppm}$.

Hasil penelitian menunjukkan bahwa pada 24 jsa, konsentrasi 10.000 ppm menyebabkan mortalitas $C$. pavonana $\mathrm{F}$. sebesar $45,32 \%$ dan tidak berbeda nyata dengan konsentrasi $5.000 \mathrm{ppm}$, akan tetapi berbeda nyata dengan konsentrasi 2.500 ppm, 1.250 ppm, 625 ppm, dan 312,5 ppm. Pada 48 jsa, konsentrasi 10.000 ppm menunjukkan mortalitas $C$. pavonana $\mathrm{F}$. sebesar $55,96 \%$, akan tetapi berbeda nyata dengan konsentrasi $5.000 \mathrm{ppm}, 2.500 \mathrm{ppm}$, dan $1.250 \mathrm{ppm}, 625 \mathrm{ppm}$, dan 312,5 ppm. Pada 72 jsa, konsentrasi 10.000 ppm dapat menyebabkan mortalitas hama $C$. pavonana $\mathrm{F}$. sebesar $58,08 \%$, akan tetapi berbeda nyata dengan konsentrasi 5.000 ppm, 2.500 ppm, 1.250 ppm, 625 ppm, dan 312,5 ppm (Tabel 3).

Aplikasi fraksi daun mint kemungkinan memberikan nilai mortalitas yang meningkat seiring dengan interval waktu pengamatan. Konsentrasi 10.000 ppm ekstrak daun mint mulai pada 48 jsa menyebabkan mortalitas $C$. pavonana $\mathrm{F}$. yang lebih tinggi dibandingkan dengan konsentrasi 5.000 ppm, 2.500 ppm, 1.250 ppm, 625 ppm, dan 312,5 ppm, kemungkinan karena mengandung bahan aktif yang lebih tinggi dibandingkan dengan konsentrasi yang lebih rendah.Ekstrak daun mint yang diaplikasikan adalah ekstrak yang tergolong dalam senyawa polar (Sastrohamidjojo, 2004) yang kemudian dilakukan pengenceran dengan air untuk dilakukan pengujian. Ekstrak daun mint kemungkinan masuk ke dalam tubuh serangga selanjutnya meracuni tubuh serangga sehingga menyebabkan mortalitas $C$. pavonana $\mathrm{F}$.

Fraksi daun mint pada konsentrasi 10.000 ppm pada 72 jsa mengakibatkan mortalitas $C$. pavonana $\mathrm{F}$. sebesar $58,08 \%$. Sebaliknya ekstrak daun mint pada konsentrasi $312.5 \mathrm{ppm}$ hanya dapat menyebabkan mortalitas $C$. pavonana $\mathrm{F}$. sebesar $34,40 \%$ (Tabel 3). Menurut Sastrohamidjojo (2004) daun mint mengandung senyawa menthol dan menthone yang dapat menyebabkan mortalitas serangga karena menghambat proses sintesis protein di dalam tubuh serangga. Dengan demikian diduga bahwa konsentrasi 10.000 ppm dari ekstrak daun mint juga mengandung senyawa menthol dan menthone yang dapat menyebabkan mortalitas $C$. pavonana $\mathrm{F}$.

\section{KESIMPULAN DAN SARAN}

Toksisitas ekstrak daun mint terhadap mortalitas C. pavonana $\mathrm{F}$. fraksi lapisan $\mathrm{H}_{2} \mathrm{O}$ lebih tinggi bila dibandingkan dengan fraksi EtOAc. Toksisitas ekstrak daun mint terhadap mortalitas $C$. pavonana F. fraksi $100 \% \mathrm{H}_{2} \mathrm{O}$ lebih tinggi bila dibandingkan dengan fraksi $20 \% \mathrm{MeOH} / \mathrm{H}_{2} \mathrm{O}, 40 \% \mathrm{MeOH} / \mathrm{H}_{2} \mathrm{O}, 60 \% \mathrm{MeOH} / \mathrm{H}_{2} \mathrm{O}$,

Tabel 2. Persentase mortalitas terkoreksi C. pavonana F. pada berbagai fraksi daun mint.

\begin{tabular}{|c|c|c|c|c|c|c|c|}
\hline \multirow{2}{*}{$\begin{array}{c}\text { Waktu } \\
\text { (jsa) }\end{array}$} & \multicolumn{6}{|c|}{ Mortalitas (\%) pada fraksi } & \multirow[t]{2}{*}{ BNT } \\
\hline & $100 \% \mathrm{H}_{2} \mathrm{O}$ & $\begin{array}{c}20 \% \\
\mathrm{MeOH} / \mathrm{H}_{2} \mathrm{O}\end{array}$ & $\begin{array}{c}40 \% \\
\mathrm{MeOH} / \mathrm{H}_{2} \mathrm{O}\end{array}$ & $\begin{array}{c}60 \% \\
\mathrm{MeOH} / \mathrm{H}_{2} \mathrm{O}\end{array}$ & $\begin{array}{c}80 \% \\
\mathrm{MeOH} / \mathrm{H}_{2} \mathrm{O}\end{array}$ & $100 \% \mathrm{MeOH}$ & \\
\hline 24 & 38,59 a & $38,85 \mathrm{a}$ & $35,44 \mathrm{~b}$ & $28,95 \mathrm{c}$ & $28,77 \mathrm{c}$ & $28,42 \mathrm{c}$ & 0,51 \\
\hline 48 & 54,09 a & $43,33 \mathrm{~b}$ & $46,90 \mathrm{c}$ & $36,81 \mathrm{~d}$ & $36,66 \mathrm{~d}$ & $36,35 \mathrm{~d}$ & 0,32 \\
\hline 72 & 60,32 a & $48,14 \mathrm{~b}$ & $47,95 \mathrm{~b}$ & $44,63 \mathrm{c}$ & $44,63 \mathrm{c}$ & $36,35 \mathrm{~d}$ & 0,31 \\
\hline
\end{tabular}

Keterangan : Angka yang diikuti huruf sama pada baris yang sama menunjukkan tidak berbeda nyata menurut uji BNT pada $\alpha_{0,05}$.

Tabel 3. Persentase mortalitas terkoreksi C. pavonana F. dari beberapa aplikasi fraksi $\mathrm{H}_{2} \mathrm{O}$ daun mint.

\begin{tabular}{cccccccc}
\hline \multirow{2}{*}{$\begin{array}{c}\text { Waktu } \\
\text { (jsa) }\end{array}$} & $10.000 \mathrm{ppm}$ & $5.000 \mathrm{ppm}$ & $2.500 \mathrm{ppm}$ & $1.250 \mathrm{ppm}$ & $625 \mathrm{ppm}$ & $312,5 \mathrm{ppm}$ & \multirow{2}{*}{ BNT } \\
\cline { 2 - 6 } & $45,32 \mathrm{a}$ & $45,04 \mathrm{a}$ & $35,25 \mathrm{~b}$ & $31,35 \mathrm{c}$ & $31,35 \mathrm{c}$ & $31,36 \mathrm{c}$ & 0,30 \\
24 & $55,96 \mathrm{a}$ & $48,65 \mathrm{~b}$ & $47,63 \mathrm{c}$ & $41,89 \mathrm{~d}$ & $36,54 \mathrm{e}$ & $31,36 \mathrm{f}$ & 0,24 \\
48 & $58,08 \mathrm{a}$ & $54,38 \mathrm{~b}$ & $50,00 \mathrm{c}$ & $45,29 \mathrm{~d}$ & $42,88 \mathrm{e}$ & $34,40 \mathrm{f}$ & 0,31 \\
72 & &
\end{tabular}

Keterangan : Angka yang diikuti huruf sama pada baris yang sama menunjukkan tidak berbeda nyata menurut uji BNT pada $\alpha_{0,05}$. 
$80 \% \mathrm{MeOH} / \mathrm{H}_{2} \mathrm{O}$ dan $100 \% \mathrm{MeOH}$. Toksisitas fraksi $100 \% \mathrm{H}_{2} \mathrm{O}$ daun mint terhadap mortalitas $C$. pavonana F. pada konsentrasi 10.000 ppm mulai 48 jam setelah aplikasi lebih tinggi bila dibandingkan dengan konsentrasi $5.000 \mathrm{ppm}, 2.500 \mathrm{ppm}, 1.250 \mathrm{ppm}, 625 \mathrm{ppm}$ dan 312,5 ppm.

\section{DAFTAR PUSTAKA}

Abbott, W.S. 1925. A methode of computing the effectiveness of an insecticide. J. Econ. Entomol. 18:265-267.

Dinas Pertanian Provinsi Lampung. 2010. Data Hasil Panen Tanaman Pangan dan Hortikultura. Dinas Pertanian Tanaman Pangan Dan Hortikultura Provinsi Lampung. Lampung. 89 hlm.

Hasibuan, R. 2003. Pestisida dan Teknik Aplikasi: Pemahaman Insektisida. Jurusan Proteksi Tanaman Fakultas Pertanian Universitas Lampung. Bandar Lampung. $102 \mathrm{hlm}$.

Hayes, J.R., N.S. Stavanja, and B.M. Lawrence. 2007. Biological and Toxicological Properties of Mint Oils and Their Major Isolates : Safety Assessment. In Mint : The Genus Mentha, Edited by B.M Lawrence. CRC Press, Taylor \& Francis Group, New York. p 421 - 495.
Kardinan, A. 2004. Pestisida Nabati Ramuan dan Aplikasi. http://one.indoskripsi.com/node/ 3090. Diakses pada tanggal 23 juli 2010.

Sarjan, M. 2008. Potensi Pemanfaatan Insektisida Nabati dalam Pengendalian Hama pada Budidaya Sayuran Organik. http:// ntb.litbangdeptan.go.id/2007/TPH/ potensipemanfaatan.doc. Diakses pada tanggal 25 juli 2010.

Sastrohamidjojo, H. 2004. Kimia Minyak Atsiri. Universitas Gadjah Mada. Yogyakarta.

Sparks, T dan A. Sparks. 1986. MicroProbit 3.0 analysis for IBM PC Compatibles (Software).

Sunarjono, H. 2003. Bertanam 30 Jenis Sayur. Penebar Swadaya. Jakarta. $183 \mathrm{hlm}$.

Supriyati. 2001. Uji efektivitas suspensi lada hitam (Piper ningrum L.) dan lada panjang (Piper retrofactum Vahl) terhadap ulat croci (Crocidolomia binotalis Zell) pada tanaman kubis. Skripsi. Fakultas Pertanian. Universitas Lampung. Bandar Lampung. $38 \mathrm{hlm}$. 